\title{
HUBUNGAN INDEKS MASSA TUBUH DENGAN USIA MENARCHE PADA SISWI SMP DI KOTA LHOKSEUMAWE
}

\author{
Julia Fitriany $^{1}$, Fury Maulina ${ }^{2}$, Cut Ela Witanti ${ }^{3}$ \\ 1 Bagian Ilmu Kesehatan Anak, Fakultas Kedokteran, Universitas Malikussaleh \\ 2 Bagian Ilmu Kesehatan Masyarakat, Fakultas Kedokteran, Universitas Malikussaleh \\ 3 Program Studi Kedokteran Fakultas Kedokteran, Universitas Malikussaleh \\ *Corresponding Author:cutellawitanti@gmail.com
}

\begin{abstract}
Abstrak
Menarche adalah periode menstruasi pertama dalam kehidupan seorang wanita dan merupakan penanda akhir perkembangan pubertas di sekitar usia 12-14 tahun. Menarche dini berhubungan dengan beberapa faktor yang meliputi keadaan gizi, genetik, sosioekonomi, hormonal, dan keterpaparan media massa orang dewasa. Penelitian ini bertujuan untuk mengetahui hubungan Indeks Massa Tubuh (IMT) dengan usia menarche pada siswi SMP di Kota Lhokseumawe. Penelitian ini menggunakan pendekatan cross sectional survey yang diadakan pada 55 siswi yang mengalami menarche dalam Januari 2018, dengan menggunakan uji kolmogorov smirnov. Responden paling banyak didapatkan dari Kecamatan Banda Sakti, usia paling banyak adalah usia 13 tahun dan diantaranya adalah kelas VII. Responden yang paling banyak didapatkan adalah IMT normal dan usia menarche dalam batas normal. Berdasarkan uji kolmogorov smirnov, didapatkan nilai $\mathrm{p}=0,992$ pada hubungan IMT dengan usia menarche. Kesimpulannya adalah tidak ada hubungan IMT dengan usia menarche pada siswi SMP di Kota Lhokseumawe.
\end{abstract}

Kata kunci : Indeks Massa Tubuh (IMT); menarche; usia menarche

\section{THE RELATIONSHIP BETWEEN BODY MASS INDEX AND AGE AT MENARCHE ON FEMALE STUDENTS IN JUNIOR HIGH SCHOOL IN KOTA LHOKSEUMAWE}

\begin{abstract}
Menarche is the first menstrual period in a women's life and as the final marker of puberty development around age 12-14 years old. Early menarche is related to several factors such as nutrients condition, genetic, socioeconomic, hormonal, and adult mass media exposure. This research aimed to identify the relationship between Body Mass Index (BMI) and age at menarche in Kota Lhokseumawe. This study used cross sectional survey with conducted for 55 female students who experienced menarche in January 2018, with kolmogorov smirnov test. The most respondents were from District of Banda Sakti, most of them were 13 years old, and they were students at grade $7^{\text {th }}$. Most of respondents were in normal BMI and age at menarche was normal. Based on kolmogorov smirnov test, we found that $\mathrm{p}=0,992$ for relationship of BMI and age at menarche. We concluded that there was no relationship between BMI and age at menarche on female students in Junior High School in Kota Lhokseumawe.
\end{abstract}

Keywords: age at menarche; Body Mass Index (BMI); menarche

\section{PENDAHULUAN}

Sejumlah risiko penyakit terkait hormonal seperti kanker payudara ${ }^{1}$, endometriosis ${ }^{2}$, diabetes melitus tipe $2^{3}$, sindrom metabolik ${ }^{4}$ dan penyakit kardiovaskular ${ }^{5}$ dikaitkan dengan penurunan usia menarche. Risiko tersebut mengindikasikan usia menarche sebagai faktor Jurnal Averrous Vol.4 No.1 2018 
penting dalam program perencanaan kesehatan, seperti pengadaan fasilitas dan informasi kesehatan yang berhubungan dengan menarche pada Sekolah Menengah Pertama (SMP) serta memaksimalkan Pelayanan Kesehatan Peduli Remaja (PKPR) pada setiap sekolah ${ }^{6}$.

Menarche adalah menstruasi pertama dan merupakan penanda akhir dari pubertas. Ia merupakan indikator dan kejadian yang paling mudah diingat dalam proses kematangan seksual wanita ${ }^{4}$. Menarche muncul pada usia 12 sampai 14 tahun atau 2 sampai 3 tahun setelah munculnya perkembangan seks sekunder (thelarche). Rata-rata usia menarche adalah 12,8 tahun, namun dalam beberapa dekade terakhir rata-rata usia menarche telah mengalami penurunan ${ }^{7}$.

Penelitian di negara-negara industri di Benua Amerika dan Eropa pada awal abad ke-20, ditemukan penurunan usia menarche sebesar 2 sampai 3 bulan tiap dekade. Usia rata-rata menarche di Amerika Serikat, sebelum tahun 1900 sampai 1988 adalah lebih dari 14 tahun dan pada tahun 1994 menurun menjadi 12,43 tahun. Usia rata-rata menarche di Benua Eropa adalah 15 tahun untuk yang lahir di tahun 1880 sampai 1890 dan menjadi 12 tahun untuk yang lahir di tahun 1970 sampai $1980^{8}$.

Usia menarche termuda di Indonesia adalah 9 tahun dan usia menarche tertua adalah 18 tahun. Usia rata-rata menarche di Indonesia adalah 12,96 tahun dengan proporsi usia 12 tahun $(31,33 \%)$, usia 13 tahun $(31,30 \%)$ dan pada usia 14 tahun $(18,24 \%)^{9}$. Usia rata-rata menarche terendah terdapat di Yogyakarta 12,45 tahun dan tertinggi di Kupang 13,86 tahun ${ }^{10}$. Usia ratarata menarche di Banda Aceh 12 sampai 13 tahun sebesar 69,5\%, pada usia kurang dari 11 tahun sebesar 10,9\% dan 19,6\% pada usia lebih 13 tahun $^{11}$.

Usia menarche yang semakin dini disebabkan oleh perbaikan nutrisi dan kesehatan secara global pada pertengahan tahun 1800 -an sampai pertengahan 1900 -an $^{12}$. Kondisi nutrisi dan kesehatan pada remaja putri dapat diketahui dari nilai Indeks Massa Tubuh (IMT). Usia menarche yang semakin dini telah dikaitkan dengan peningkatan IMT. Usia menarche yang lebih dini pada remaja putri dengan IMT berlebih ditemukan lebih banyak dibandingkan IMT yang normal atau kurus Penurunan usia menarche, tidak ditemukan pada remaja putri dengan perawakan kurus juga mendukung bukti IMT sebagai faktor terkuat penyebab penurunan usia menarche $e^{13}$.

National Health and Nutrition Examination Survey (NHNES) menemukan IMT dengan kategori obesitas di dunia terus meningkat dari sekitar 9,4\% menjadi $14,5 \%$ pada NHANES I (1971 sampai 1974), NHANES II (1976 sampai 1980) menjadi 22,5\%, NHANES III (1988 sampai 1994), menjadi 30\% pada survei tahun 1999-2000 ${ }^{14}$. National Health and Nutrition Jurnal Averrous Vol.4 No.1 2018 
Examination Survey IV (2007 sampai 2008) di Amerika Serikat, ditemukan bahwa penduduk yang gemuk sebanyak 34,2\% dan obesitas 33,8\%. Rata-rata IMT di Amerika Serikat pada tahun 2009 sampai 2010 sebesar $28,7 \mathrm{~kg} / \mathrm{m}^{2}$. Rata-rata obesitas pada wanita sebesar $35,8 \%{ }^{15}$.

Survei di Taiwan dan Hongkong, menunjukkan bahwa satu dari empat anak mengalami IMT dengan kategori gemuk ${ }^{16}$. The International Diabetes Federation (IDF) dalam Anggelia dan Kusmaedi (2017) ${ }^{17}$ mengestimasikan jumlah individu yang akan mengalami obesitas di seluruh dunia menjelang tahun 2025 akan mencapai sekitar 380 juta orang, dan lebih dari setengah penderita itu tinggal di Asia. Salah satu diantaranya adalah di China mengalami peningkatan sekitar 15\% dengan IMT kategori gemuk dan obesitas antara tahun 1980 (3,7\%) dan 2002 (19\%). Indonesia pada tujuh provinsi didapatkan IMT dengan nilai bervariasi dari 18,6 sampai $19,5 \mathrm{~kg} / \mathrm{m}^{2}$ termasuk dalam kategori normal ${ }^{10}$. Rata-rata IMT di Indonesia terutama Manado yaitu kurus sebesar 29,1\%, normal sebesar 51,5\% dan gemuk sebesar $19,4 \%{ }^{18}$.

Rata-rata IMT di Aceh terutama pada Gampong Klieng Cot Aron Kecamatan Baitussalam Aceh Besar tahun 2013 dari 205 responden mayoritas siswi dengan obesitas sebanyak 67 orang sebesar $32.7 \%{ }^{11}$. Rata-rata IMT di Lhokseumawe adalah kurus $(35,6 \%)$, normal $(37,7 \%)$, gemuk $(19,4 \%)$ dan obesitas $(7,3 \%)^{19}$.

Putra, Ermawati dan Amir (2016) tentang hubungan IMT dengan usia menarche pada siswi SMP Negeri 1 Padang ditemukan sebanyak 27 orang $(35,1 \%)$ responden memiliki IMT dengan kategori kurus, 47 orang (61\%) dengan kategori normal, dan 3 orang (3,9\%) dengan kategori gemuk dengan nilai $\mathrm{p}=0,000(\mathrm{p}<0,05)$ dan $\mathrm{r}=-0,429$. Hasil penelitian tersebut menunjukkan bahwa semakin tinggi IMT, maka semakin cepat terjadi menarche ${ }^{20}$.

\section{METODE}

Jenis penelitian ini adalah analitik observasional dengan pendekatan cross-sectional. Populasi penelitian adalah seluruh siswi SMP kelas VII, VIII, IX tahun akademik 2017-2018 di Kota Lhokseumawe sebanyak 18 sekolah yaitu di Kecamatan Banda Sakti (8 sekolah), Kecamatan Blang Mangat (4 sekolah), Kecamatan Muara Satu (3 sekolah) dan Kecamatan Muara Dua (2 sekolah) dengan total siswi adalah 3.334 orang. Penelitian dilakukan selama bulan Agustus 2017 sampai April 2018. Teknik pengambilan sampel adalah total sampling, sehingga didapatkan 55 siswi sebagai responden. Sampel yang diambil adalah yang memenuhi kriteria inklusi dan ekslusi sebagai berikut: 1) Responden merupakan siswi SMP kelas VII sampai IX; 2) Responden mengalami menarche dalam satu bulan terakhir terhitung Jurnal Averrous Vol.4 No.1 2018 
sejak 1 Januari 2018; 3) Responden yang bersedia menjadi sampel penelitian. Kriteria eksklusi: 1) Responden tidak hadir saat penelitian berlangsung (cuti, sakit); 2) Responden yang memiliki penyakit yang telah didiagnosis oleh dokter seperti penyakit kronis (kanker payudara dan sindrom metabolik), penyakit autoimun (penyakit grave dan sistemik lupus eritematosus) atau pengobatan jangka panjang (penggunaan steroid dan kemoterapi).

Variabel penelitian adalah IMT sebagai variabel independen dan usia menarche sebagai variabel dependen. Instrumen yang digunakan berupa kuisioner untuk mengetahui usia menarche dan menyamakan kriteria eklusi dan inklusi. Pengukuran berat badan dan tinggi badan dengan menggunakan timbangan berat badan dan microtoise merek GEA untuk mendapatkan nilai IMT. Pada penelitian ini digunakan uji Chi Square dengan uji alternatif yaitu uji Kolmogorov Smirnov. Jika berdasarkan hasil uji didapatkan nilai $\mathrm{p}<0,05$, maka terdapat hubungan yang bermakna antara kedua variabel, sedangkan jika nilai $\mathrm{p}>0.05$ maka tidak ada hubungan yang bermakna antara kedua variabel.

\section{HASIL}

Penelitian ini didapatkan hasil yang dapat dilihat dalam tabel berikut:

\section{Demografi Siswi SMP di Kota Lhokseumawe}

Tabel 1. Demografi siswi SMP

\begin{tabular}{llcc}
\hline \multicolumn{1}{c}{ Distribusi Responden } & Frekuensi (n) & Persentase (\%) \\
\hline I. Asal Sekolah & & & \\
\hline $\begin{array}{c}\text { A. Kecamatan } \\
\text { Banda Sakti }\end{array}$ & 1. SMPN 1 & 5 & 9,1 \\
& 2. SMPN 2 & 11 & 20,0 \\
& 3. SMPN 3 & 6 & 10,9 \\
& 4. SMPN 4 & 3 & 5,5 \\
& 5. SMPN 5 & 5 & 9,1 \\
& 6. SMPN 12 & 2 & 3,6 \\
& 7. SMPN 15 & 2 & 3,6 \\
& 8. SMPS IT Al-Markazul Islami & 2 & 3,6 \\
B. Kecamatan & 1. SMPN 6 & 4 & 7,3 \\
Muara Satu & 2. SMPN 8 & 1 & 1,8 \\
& 3. SMPS Islam Pase & 0 & 0
\end{tabular}




\begin{tabular}{clcc} 
C. Kecamatan & 1. SMPN 7 & 7 & 12,7 \\
Muara Dua & 2. SMPN 13 & 2 & 3,6 \\
& 3. SMPN 14 & 0 & 0 \\
D. Kecamatan & 1. SMPN 9 & 0 & 0 \\
Blang & 2. SMPN 10 & 1 & 1,8 \\
Mangat & 3. SMPN 11 & 3 & 5,5 \\
& 4. SMPS 1 Serambi Mekkah & 1 & 1,8 \\
\hline II. Usia & 12 tahun & & 27,3 \\
\hline & 13 tahun & 15 & 43,6 \\
& 14 tahun & 24 & 21,8 \\
& 15 tahun & 12 & 7,3 \\
\hline III. Kelas & VIII & 4 & 7,3 \\
\hline & IX & 14 & 25,5 \\
\hline
\end{tabular}

Tabel 1. menunjukkan bahwa dari 55 sampel penelitian, proporsi asal sekolah yang memiliki jumlah siswi terbanyak adalah Kecamatan Banda Sakti yaitu sebanyak 36 orang $(65,4 \%)$. Setiap sekolah memiliki beberapa sampel, namun terdapat 3 sekolah yang tidak memiliki sampel yaitu SMPN 9, SMPN 14 dan SMPS Islam Pase. Proporsi usia siswi SMP terbanyak adalah usia 13 tahun yaitu sebanyak 24 orang (43,6\%), sedangkan usia 15 tahun memiliki proporsi yang paling sedikit yaitu sebanyak 4 orang (7,3\%). Proporsi kelas pada siswi SMP terbanyak adalah kelas VII yaitu sebanyak 37 orang (67,3\%), sedangkan kelas IX memiliki proporsi yang paling sedikit yaitu sebanyak 4 orang $(7,3 \%)$. 


\section{Distribusi Frekuensi IMT pada Siswi SMP di Kota Lhokseumawe}

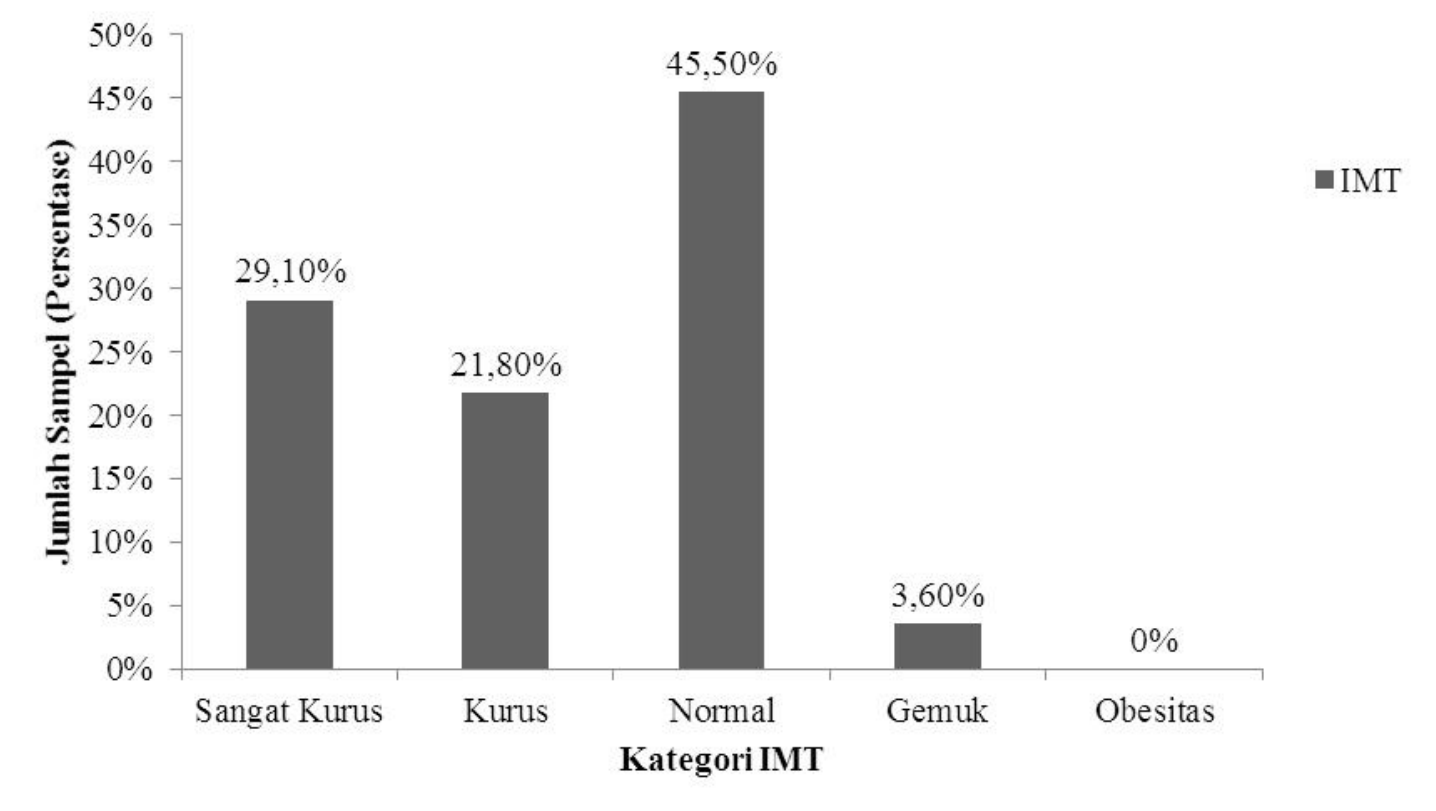

\section{Gambar 1. Grafik Distribusi Frekuensi IMT}

Gambar 1. grafik menunjukkan bahwa sebagian besar responden memiliki IMT dengan kategori normal yaitu 25 orang (45,5\%), sedangkan sebanyak 16 orang $(29,1 \%)$ memiliki IMT dengan kategori sangat kurus, sebanyak 12 orang $(21,8 \%)$ dengan kategori kurus, dan sebanyak 2 orang $(3,6 \%)$ dengan kategori gemuk dan kategori obesitas tidak ditemukan

\section{Distribusi Frekuensi Usia Menarche pada Siswi SMP di Kota Lhokseumawe}

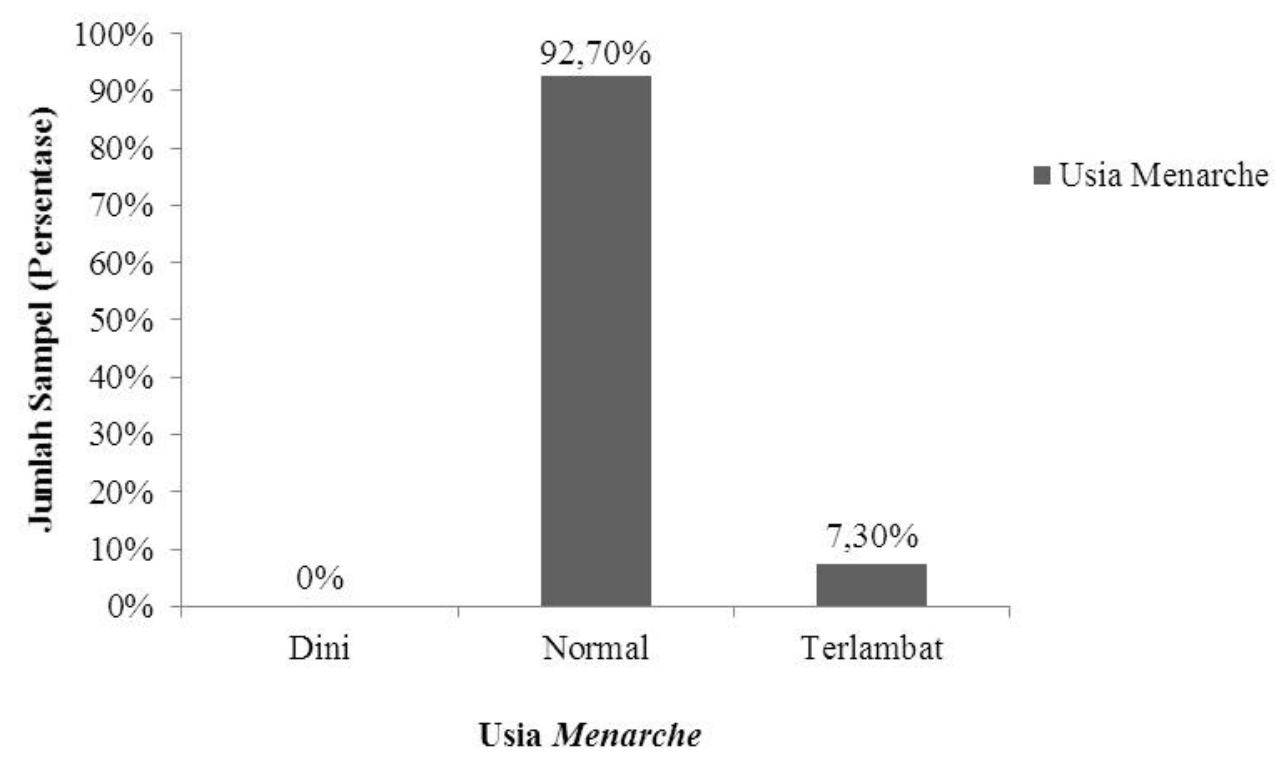

Gambar 2. Grafik Distribusi Frekuensi Usia Menarche

Jurnal Averrous Vol.4 No.1 2018 
Gambar 2. grafik menunjukkan bahwa siswi SMP yang menarche dalam batas normal terbanyak adalah 51 orang $(92,7 \%)$, sedangkan yang menarche terlambat adalah 4 orang (7.3\%) dan siswi SMP yang menarche dini tidak ditemukan.

\section{Hubungan IMT dengan Usia Menarche pada Siswi SMP di Kota Lhokseumawe}

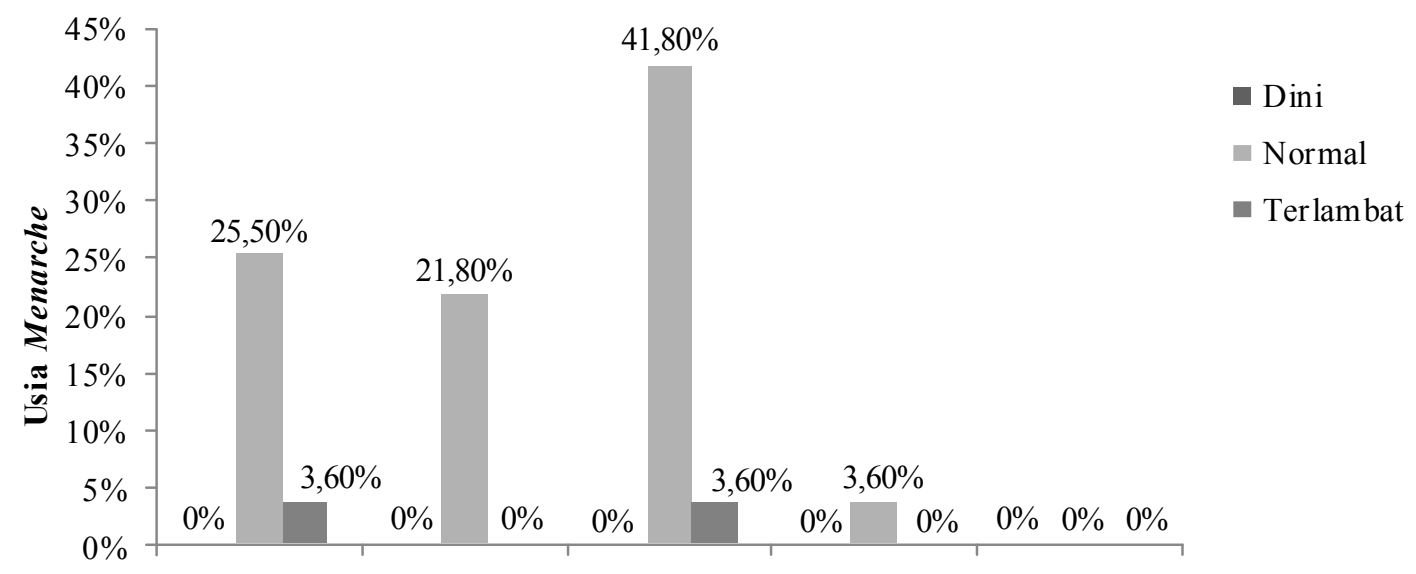




$\begin{array}{llll}\text { Sangat Kurus } & \text { Kurus } & \begin{array}{c}\text { Normal } \\ \text { IMT }\end{array} & \text { Gemuk }\end{array}$ Obesitas

\section{Gambar 3. Grafik Hubungan IMT dengan Usia Menarche}

Gambar 3. grafik menunjukkan bahwa siswi SMP yang memiliki IMT dalam kategori normal dan mengalami usia menarche dengan batas normal terbanyak yaitu sebanyak 23 orang (41,8\%), sedangkan yang memiliki IMT dengan kategori sangat kurus dan normal $(3,6 \%)$ mengalami menarche terlambat. Hasil uji Chi-Square $\left(\mathrm{X}^{2}\right)$ didapatkan nilai $\mathrm{p}$ sebesar 0,992 $(>0,05)$, sehingga $\mathrm{H} 0$ diterima. Hal ini menunjukkan bahwa tidak terdapat hubungan IMT dengan usia menarche pada siswi SMP di Kota Lhokseumawe.

\section{PEMBAHASAN}

Demografi siswi SMP di Kota Lhokseumawe berdasarkan asal sekolah, usia dan kelas. Hasil dari analisis univariat 55 responden menunjukkan bahwa proporsi asal sekolah terbanyak terdapat pada Kecamatan Banda Sakti yaitu sebanyak 36 orang $(65,4 \%)$. Hal ini dikarenakan sekolah pada kecamatan tersebut memiliki jumlah siswi terbanyak yaitu sebanyak 1794 orang dan terletak di area perkotaan sehingga memiliki peluang lebih besar untuk mendapatkan responden yang baru mengalami menarche dalam sebulan terakhir yaitu Januari 2018 (Data Primer, 2018). Hal ini sesuai dengan penelitian Indaryani (2009) ${ }^{21}$ yang menunjukkan bahwa terdapat perbedaan bermakna antara responden di pedesaan dan perkotaan dengan nilai $\mathrm{p}<0,001 \quad(<0,005)$. Penduduk di daerah perkotaan umumnya mempunyai tingkat sosial ekonomi dan pendidikan lebih tinggi dibandingkan di daerah pedesaan. Pendidikan ini berpengaruh terhadap jenis pekerjaan dan akhirnya berpengaruh pada penghasilan keluarga yang berperan besar dalam menentukan status ekonomi keluarga.

Adanya perbedaan status ekonomi dan status gizi antara anak perempuan di daerah perkotaan dan pedesaan menyebabkan perbedaan bermakna usia awitan pubertas antara anak perempuan di perkotaan dan pedesaan. Anak perempuan di perkotaan mengalami pubertas lebih awal dibandingkan anak perempuan di pedesaan. Perbedaan usia awitan pubertas ini disebabkan oleh status gizi yang baik $^{22}$. Selain itu, awitan pubertas yang lebih dini berhubungan dengan IMT adalah faktor genetik, media komunikasi, stressor, infeksi, gangguan makan, depresi, obesitas dan pematangan aksis hipothalamus-hipofisis-gonad ${ }^{23}$.

Anak perempuan yang gemuk dan obesitas mempunyai jaringan lemak yang banyak. Jaringan lemak memproduksi leptin. Kadar leptin dalam darah berhubungan dengan jumlah lemak tubuh dan IMT. Kadar leptin meningkat pada anak obesitas dan menurun pada anak Jurnal Averrous Vol.4 No.1 2018 
yang mengalami malnutrisi. Leptin mempunyai peranan penting dalam terjadinya pubertas dan pematangan aksis hipothalamus-hipofisis-gonad. Leptin dapat bekerja secara langsung maupun tidak langsung pada neuron yang menghasilkan GnRH di hipothalamus dan meningkatkan produksi GnRH, sehingga awitan pubertas melalui sinyal hormonal yang berasal dari jaringan lemak ${ }^{22}$.

Hasil dari analisis univariat 55 responden menunjukkan bahwa proporsi usia siswi SMP terbanyak adalah usia 13 tahun yaitu sebanyak 24 orang $(43,6 \%)$ dan proporsi kelas pada siswi SMP terbanyak adalah kelas VII yaitu sebanyak 37 orang $(67,3 \%)$. Hal ini sesuai dengan Riset Kesehatan Dasar tahun $(2010)^{9}$ menunjukkan bahwa rata-rata usia menarche pada perempuan usia 10-59 tahun di Indonesia adalah 13 tahun dengan kejadian lebih awal pada usia kurang dari 9 tahun. Usia rata-rata menarche di Indonesia adalah 12,96 tahun. Hal ini disebabkan oleh peran gizi dan status ekonomi pada usia menarche ${ }^{10}$.

Peningkatan asupan energi dan nutrisi telah dikaitkan dengan usia menarche dini. Hal ini dipengaruhi oleh adanya massa lemak pada permulaan pubertas dan terjadinya menarche dan untuk mempertahankan kapasitas reproduksi. Hal ini juga berhubungan dengan IMT, massa lemak, kadar leptin, pengaruh ras dan faktor lingkungan lainnya. Peningkatan IMT pada usia 3 dan 6 tahun merupakan faktor risiko yang signifikan pada anak perempuan untuk memasuki pubertas yang lebih dini. Kadar leptin ditemukan jauh lebih tinggi pada anak perempuan yang memiliki IMT yang obesitas daripada anak dengan IMT yang normal. Peningkatan serum leptin sudah ditetapkan 2 tahun sebelum peningkatan serum LH dan estradiol. Leptin sangat berhubungan dengan massa lemak tubuh dan penurunan usia menarche $e^{10}$.

Hasil dari analisis univariat 55 responden yang mengalami menarche pada siswi SMP di Kota Lhokseumawe dalam bulan Januari 2018 didapatkan bahwa siswi SMP dengan kategori normal yang terbanyak yaitu sebanyak 25 orang (45,5\%), sedangkan kategori sangat kurus sebanyak 16 orang $(29,1 \%)$, kategori kurus sebanyak 12 orang $(21,8 \%)$, kategori gemuk sebanyak 2 orang $(3,6 \%)$ dan kategori obesitas tidak ditemukan (Data Primer, 2018). Hasil penelitian ini sesuai dengan penelitian yang dilakukan oleh Wulandari, Aini dan Astuti $(2015)^{24}$ yang menunjukkan responden terbanyak memiliki IMT normal (45,5\%), namun memiliki responden dengan kategori gemuk sebanyak (12,5\%). Jumlah IMT yang baik menunjukkan pemenuhan nutrisi yang optimal. Nutrisi yang optimal dapat membantu mempercepat pertumbuhan dan perkembangan organ seksual, sedangkan tidak terpenuhinya nutrisi dapat berakibat terlambatnya pematangan seksual dan hambatan pertumbuhan ${ }^{25}$. 
Jumlah IMT dipengaruhi oleh beberapa hal, seperti asupan nutrisi, pola makan, aktivitas fisik, gaya hidup, status sosial-ekonomi, tingkat pendidikan, tingkat pengetahuan, keadaan lingkungan, paparan penyakit kronis dan persentase lemak $^{26}$. Semakin tinggi asupan nutrisi maka semakin tinggi kemungkinan seseorang mengalami peningkatan IMT. Asupan nutrisi ini dipengaruhi oleh pola makan, tingkat pendidikan dan pengetahuan, status sosial-ekonomi. Semakin sering seseorang makan, maka makin tinggi pula asupan nutrisinya, begitu pula dengan tingkat pendidikan dan pengetahuan yang berpengaruh terhadap jenis makanan yang dikonsumsi. Tingginya status sosial-ekonomi juga dapat meningkatkan daya beli seseorang untuk memenuhi kebutuhan nutrisinya. Tingkat pendidikan, pengetahuan dan tingkat sosioekonomi juga dapat mempengaruhi gaya hidup dan aktivitas seseorang sehari-hari dan akhirnya mempengaruhi $\mathrm{IMT}^{27}$.

Hasil penelitian dari analisis univariat pada 55 responden pada siswi SMP di Kota Lhokseumawe yang mengalami menarche dalam bulan Januari 2018 didapatkan bahwa siswi SMP yang terbanyak adalah usia 13 tahun yaitu 24 orang $(43,6 \%)$ dan yang paling sedikit adalah usia 15 tahun yaitu 4 orang (7,3\%). Usia menarche siswi SMP yang mengalami menarche dalam batas normal yaitu 51 orang $(92,7 \%)$, sedangkan yang mengalami menarche terlambat adalah 4 orang $(7.3 \%)$ dan siswi SMP yang mengalami menarche dini tidak ditemukan (Data Primer, 2018).

Hasil penelitian ini sesuai dengan Riset Kesehatan Dasar tahun (2010) ${ }^{9}$ menunjukkan bahwa rata-rata usia menarche pada perempuan usia 10-59 tahun di Indonesia adalah 13 tahun dengan kejadian lebih awal pada usia kurang dari 9 tahun. Usia rata-rata menarche di Indonesia adalah 12,96 tahun. Hal ini disebabkan oleh peran gizi dan status ekonomi pada usia menarche. Hal tersebut dikarenakan adanya perubahan hormon yang mempengaruhi kematangan sel dan paparan estrogen yang berasal dari konsumsi makanan ataupun rangsangan dari luar. Paparan esterogen yang berasal dari makanan derivat esterogen (daidzein) yang banyak terdapat dalam kedelai, bengkoang dan zat kimia pada pestisida Dichloro-Diphenyl-Trichloroethane (DDT). Selain itu, anak yang sering menikmati hal yang bersifat "dewasa" baik secara audio maupun visual dari tontonan dan cerita, dapat menciptakan memori pada otak dan menimbulkan rangsangan yang akan mempengaruhi sekresi hormon-hormon seksual dan mempercepat usia menarche ${ }^{28}$.

Data yang diperoleh dari hasil uji statistik menunjukkan bahwa responden dengan IMT kategori normal dan mengalami usia menarche dalam batas normal adalah sebanyak 23 orang $(41,8 \%)$, sedangkan yang memiliki IMT kategori sangat kurus dan normal $(3,6 \%)$ mengalami Jurnal Averrous Vol.4 No.1 2018 
menarche terlambat. Hasil uji Chi-Square $\left(\mathrm{X}^{2}\right)$ dengan menggunakan uji alternatif yaitu Kolmogorov Smirnov didapatkan nilai p sebesar 0,992 berarti tidak terdapat hubungan IMT dengan usia menarche pada siswi SMP di Kota Lhokseumawe (Data Primer, 2018).

Hasil ini sejalan dengan penelitian Himes, Park dan Styne $(2009)^{29}$ yang menyebutkan bahwa IMT bukan satu-satunya penentu dalam penurunan usia menarche dan efek rata-rata usia menarche pada penilaian IMT dengan kategori gemuk dan obesitas adalah kecil dan biasanya tidak penting secara klinis. Hal ini sesuai dengan penelitian Garn, La dan Pilkington $(1983)^{30}$ dan Sherar, Baxter-Jones dan Mirwald (2007) $)^{31}$ yang menyebutkan bahwa tidak ada bukti yang jelas tentang tingkat ambang berat badan atau massa lemak dalam tubuh untuk penurunan usia menarche.

Menarche dan IMT tidak terdapat hubungan karena disebabkan oleh adanya pengaruh faktor genetik terhadap menarche. Menarche sangat erat hubungannya dengan masa puncak kecepatan penambahan tinggi badan. Masa ini ditentukan oleh berbagai faktor, tetapi faktor terpenting adalah faktor genetik ${ }^{5}$. Hubungan erat ditemukan antara usia menarche ibu dengan putrinya, dan lebih erat lagi antar usia menarche perempuan yang bersaudara ${ }^{22}$. Faktor lain yang berperan adalah status gizi, anak perempuan yang gemuk akan mendapat menarche lebih awal daripada yang kurus. Semua penyakit kronik yang mengganggu status gizi atau oksigenasi jaringan akan memperlambat pola maturasi pubertas, terutama waktu menarche ${ }^{32}$. Anak yang sering menikmati hal yang bersifat "dewasa" baik secara audio maupun visual dari tontonan dan cerita, dapat menciptakan memori pada otak dan menimbulkan rangsangan yang akan mempengaruhi sekresi hormon-hormon seksual dan mempercepat usia menarche ${ }^{28}$.

Hasil penelitian ini tidak sejalan dengan penelitian Pujiani $(2012)^{33}$ yang menyebutkan bahwa terdapat hubungan yang bermakna antara status gizi dengan usia menarche. Hal yang membuat hasil penelitian ini berbeda dengan penelitian Pujiani adalah penelitian yang dilakukan menggunakan uji Chi-Square dengan teknik propotionate startified random sampling, sedangkan peneliti menggunakan uji Chi-Square dengan teknik total sampling dengan sampel siswi SMP yang mengalami menarche dalam sebulan terakhir (Januari 2018). Siswi yang memiliki IMT yang lebih tinggi cenderung mendapatkan menarche terlebih dahulu, hal ini dikarenakan kadar leptin yang disekresikan oleh kelenjar adiposa dan leptin mempengaruhi kadar neuropeptida Y yang mempengaruhi GnRH. Perubahan kadar GnRH yang disekresikan juga mengubah kadar sekresi $\mathrm{LH}^{34}$. Selain itu, kadar leptin berpengaruh pada maturasi oosit yang merangsang pematangan ovum yang dihasilkan oleh ovarium. Oleh sebab itu, dapat disimpulkan bahwa siswi yang memiliki nilai IMT yang tinggi akan Jurnal Averrous Vol.4 No.1 2018 
mengalami menarche di usia yang lebih muda dibanding mereka yang memiliki nilai IMT rendah, karena perbedaan jumlah kelenjar adiposa menghasilkan jumlah sekresi kadar leptin yang berbeda ${ }^{28}$.

Anak perempuan yang memiliki nilai IMT diatas normal akan mendapatkan usia menarche yang lebih dini Hal ini disebabkan oleh banyaknya faktor yang saling berinteraksi dalam mempengaruhi menarche. Secara fisiologis, menarche dialami oleh perempuan setelah mengalami peningkatan kadar GnRH, LH dan FSH yang biasanya dimulai pada usia 8 tahun. Hormon ini dapat meningkatkan kadar estrogen serta memicu pertumbuhan dan perkembangan organ seksual, termasuk penebalan endometrium yang nantinya akan meluruh (menstruasi). Terpicunya GnRH ini dipengaruhi interaksi dari banyak faktor, salah satunya adalah IMT. Indeks Massa Tubuh yang meningkat pada anak perempuan menunjukkan jaringan lemak yang tinggi sehingga dapat menimbulkan menarche lebih dini akibat meningkatnya kadar leptin yang memberikan sinyal ke otak ${ }^{35}$.

Nutrisi mempengaruhi kematangan seksual pada anak perempuan yang mengalami menarche dini, cenderung lebih matang anak perempuan yang sudah mengalami menarche dibandingkan dengan anak perempuan yang belum mengalami menarche. Sebaliknya pada anak perempuan yang menarche terlambat, kecendrungan kematangannya lebih kecil daripada yang sudah mengalami menarche, walaupun TB anak perempuan tersebut sama. Anak perempuan yang lebih dini matang akan memiliki IMT yang lebih tinggi dan anak perempuan yang matang terlambat memiliki IMT lebih kecil pada usia yang sama ${ }^{12}$.

Faktor-faktor yang dapat berinteraksi dengan IMT dengan usia menarche dapat mempengaruhi hasil penelitian. Keterbatasan penelitian ini adalah sampel yang memenuhi kriteria inklusi yang spesifik, yaitu siswi SMP yang mengalami menarche pada bulan Januari

2018, sehingga sampel yang didapatkan sedikit yaitu 55 orang $(1,6 \%)$ dari 3.334 orang. Selain sampel yang spesifik, sampel yang kemungkinan termasuk dalam kriteria inklusi, siswi tersebut tidak mengakui bahwa ia telah menarche dalam bulan Januari 2018 atau ragu untuk mengakui hal tersebut dan juga guru ataupun siswi yang merasa tabu jika memberitahukan kepada orang lain perihal menstruasi. Keterbatasan lainnya adalah penelitian ini menggunakan metode cross sectional survey yang tidak menggambarkan perjalanan penyakit, insidensi, maupun prognosis, dan dibutuhkan jumlah subyek yang cukup banyak. Selain itu, pemeriksaan pada penelitian ini dilakukan tanpa memperhitungkan beberapa faktor lain seperti asupan nutrisi yang seharusnya di follow-up secara berkala sebelum menarche. Asupan nutrisi yg di follow-up, kita dapat mengetahui sejauh apa pengaruh asupan lemak sebagai Jurnal Averrous Vol.4 No.1 2018 
bahan bakar pembentukan hormon estrogen untuk menimbulkan menarche dini. Penelitian ini juga kurang memperhitungkan faktor lain seperti derivat estrogen pada makanan atau suplemen yang tidak dapat dideteksi. Fuadah $(2016)^{33}$ menyebutkan bahwa pengaruh estrogen terhadap hasil penelitian mengenai menarche dan status gizi karena anak memiliki sensitivitas yang tinggi terhadap estrogen dan derivatnya, namun bergantung kepada jenis zat, dosis, dan lama paparan.

\section{SIMPULAN}

Berdasarkan hasil penelitian dan pembahasan, didapatkan kesimpulan hasil penelitian ini adalah proporsi sampel dalam bulan Januari 2018 terbanyak berasal dari Kecamatan Banda Sakti, usia 13 tahun, kelas VII, IMT dan usia menarche dalam batas normal, sehingga tidak terdapat hubungan IMT dengan usia menarche pada siswi SMP di Kota Lhokseumawe.

\section{SARAN}

Berdasarkan hasil penelitian yang telah dilakukan, maka dapat peneliti sarankan yaitu bagi dinas kesehatan diharapkan untuk bekerja sama dengan pihak sekolah agar dapat memberikan edukasi kepada siswi tentang masalah kesehatan reproduksi lebih dini khususnya tentang menstruasi seiring dengan adanya percepatan usia menarche. Siswi juga diberikan pengetahuan mengenai sikap dan perilaku yang tepat untuk menghadapi menstruasi dan diberikan pengetahuan untuk menjaga kesehatan organ reproduksi saat menghadapi menstruasi untuk mencegah munculnya masalah-masalah kesehatan reproduksi; Bagi peneliti selanjutnya, diharapkan melakukan penelitian kepada siswi Sekolah Dasar (SD) dan SMP agar menemukan siswi yang mengalami menarche dini dan terlambat; Diperlukan penelitian lebih lanjut untuk menyempurnakan penelitian ini dan variabel lain yang berhubungan dengan kejadian menarche.

\section{DAFTAR PUSTAKA}

1. Ritter R, Lukanova A, Tjonneland A, Olsen A, Overvad K, Mesrine S, et al. Height, age at menarche and risk of hormone receptor-positive and -negative breast cancer: $\mathrm{A}$ cohort study. Int J Cancer. 2013;132(11):2619-2629.

2. Nnoaham KE, Webster P, Kumbang J, Kennedy SH, Zondervan KT. Is early age at menarche a risk factor for endometriosis? A systematic review and meta-analysis of case-control studies. Fertil Steril. Elsevier Inc.; 2012;98(3):702-712.e6.

3. Harjutsalo V, Maric-bilkan C, Forsblom C. Age at menarche and the risk of diabetic Jurnal Averrous Vol.4 No.1 2018 
microvascular complications in patients with type 1 diabetes. Springer. 2016;(59):47280.

4. Al-awadhi N, Al-kandari N, Al-hasan T, Almurjan D, Ali S, Al-taiar A. Age at menarche and its relationship to body mass index among adolescent girls in Kuwait. BMC Public Health. BMC Public Health; 2013;13(1):1-7.

5. Jahanfar S, Lye M-S, Krishnarajah IS. Genetic and environmental effects on age at menarche, and its relationship with reproductive health in twins. Indian J Hum Genet. $2013 ; 19(2): 245-51$.

6. Kementrian kesehatan Republik Indonesia. Profil Kesehatan Indonesia. 2015. 142-143 p.

7. Kliegman RM, Stanton BF, Geme JW St., Schor NF. Nelson textbook of pediatrics. 20th ed. Behrmen RE, editor. Philadelphia: Elsevier; 2015. 84-90 p.

8. Yermachenko A, Dvornyk V. Nongenetic Determinants of Age at Menarche: A Systematic Review. Biomed Res Int. 2014;10(11):1-14.

9. Riset Kesehatan Dasar. Laporan Nasional Riset Kesehatan Dasar. 2010.

10. Batubara JRL, Soesanti F, Waal HD Van De. Age at Menarche in Indonesian Girls : A National Survey. Acta Medica Indones J. 2010;42(2):78-81.

11. Suliawati G. Hubungan umur, paritas dan status gizi dengan kejadian dismenore pada wanita usia subur di Gampong Klieng Cot Aron Kecamatan Baitussalam Aceh Besar. 2013 .

12. Peters S, Huxley R, Woodward M. Women's reproductive health factors and body adiposity: findings from the UK Biobank. Int J Obes. Nature Publishing Group; 2016;40(5):803-8.

13. Fritz MA, Speroff L. Clinical Ginecologic Endocrinology an Infertility. 8th ed. Philadelphia: Lippincott Williams \& Willkins; 2010.

14. Elim C, Pangemanan DHC, Supit S, Lindo V, Warouw SM. Gambaran Kadar Low Density Lipoprotein (LDL) pada Siswa-Siswi Overweight dan Obesitas di Kota Manado. J Biomedik. 2012;4(3):69-76.

15. Flegal KM, Carroll MD, Kit BK, Ogden CL. Prevalence of Obesity and Trends in the Distribution of Body Mass Index Among US Adults, 1999-2010. J Am Med Assoc. 2017;307(5):491-7.

16. Gill TG. Young People with Diabetes and Obesity in Asia. Diabetes Voice. 2012;52:20-2.

17. Anggelia DA, Kusmaedi N. Hubungan Aktivitas Fisik dengan Indeks Massa Tubuh Siswa Late Adolescenes. J Terap Ilmu Keolahragaan. 2017;(1):227-34.

18. Munda SS, Wagey FW, Wantania J. Hubungan antara IMT dengan usia menarche pada siswi SD dan SMP di Kota Manado. J Kesehat Bagian Obstet dan Ginekol Fak Kedokt Univ Sam Ratulangi. 2013;1(1).

19. Dinas Kesehatan Kota Lhokseumawe. Penilaian Status Gizi pada Remaja. 2016.

Jurnal Averrous Vol.4 No.1 2018 
20. Putra RNY, Ermawati, Amir A. Hubungan Indeks Massa Tubuh (IMT) dengan Usia Menarche pada Siswi SMP Negeri 1 Padang. J Kesehat Andalas. 2016;5(3):551-7.

21. Indaryani W. Awitan pubertas anak perempuan di pedesaan dan perkotaan: Hubungannya dengan status sosial ekonomi dan status gizi. Tesis. 2009;

22. Deardorff J, Berry-Millett R, Rehkopf D, Luecke E, Lahiff M, Abrams B. Maternal Prepregnancy BMI, Gestational Weight Gain, and Age at Menarche in Daughters. Matern Child Heal J. 2013;17:1391-8.

23. Batubara JR. Adolescent Development. Vol. 12, Sari Pediatri. 2010. 21-29 p.

24. Wulandari P, Aini DN, Astuti SuW. Faktor-faktor yang berhubungan dengan kejadian menarche siswi di SMPN 31 Semarang. J Keperawatan. 2015;6(2):117-22.

25. Amaliah N, Sari K, Rosha BC. Stunting Increased Risk of Delaying Menarche on Female Adolescent. J Gizi Makanan. 2012;35(2):150-8.

26. Dewi ACN, Mahmudiono T. Hubungan Pola Makan, Aktivitas Fisik, Sikap, dan Pengetahuan Tentang Obesitas dengan Status Gizi Pegawai Negeri Sipil di Kantor Dinas Kesehatan Provinsi Jawa Timur. J Media Gizi Indones. 2013;9(1):42-8.

27. Ruslie RH, Darmadi. Analisis Regresi Logistik untuk Faktor-faktor yang Mempengaruhi Status Gizi Remaja. Maj Kedokt Andalas. 2012;36(1):62-72.

28. Kisswardhani AD, Ambarwati, Astuti D. Hubungan Antara Status Gizi, Tingkat Paparan Media Massa Dan Faktor Keturunan Dengan Usia Menarche Pada Siswi Di SMP Negeri 1 Subah Kabupaten Batang. J Ilmu Kesehat Univ Muhammadiyah Surakarta. 2014;4-16.

29. Himes JH, Park K, Styne D. Menarche and assessment of body mass index in adolescent girls. J Pediatr. 2009;155:393-340.

30. Garn SM, La VM, Pilkington JJ. Comparison of fatness in premenarcheal girls of the same age. J Pediatr. 1983;103:328-59.

31. Sherar LB, Baxter-Jones ADG, Mirwald RL. The relationship between body composition and onset of menarche. Ann Hum Biol. 2007;34(6):673-7.

32. Bubach S, Manezes AMB, Barros FC, Wehrmeister FC, Goncalves H, Assuncao MCF, et al. Impact of the age at menarche on body composition in adulthood: results from two birth cohort studies. BMC Public Health. BMC Public Health; 2016;16:1-8.

33. Pujiani. Hubungan antara Status Gizi dengan Usia Menarche. J Kesehat Darul Ulum Jombang. 2012;1-7.

34. Fuadah F. Hubungan antara Status Gizi dengan Usia Menarche pada Remaja Putri di SMP Umi Kulsum Banjaran Kab. Bandung Provinsi Jawa Barat Tahun 2016. J Ilmu Kesehat. 2016;10(2):707-14.

35. Shah NR, Braverman ER. Measuring Adiposity in Patients: The Utility of Body Mass Index (BMI), Percent Body Fat, and Leptin. Plos One J. 2012;7(4):1-8 